\title{
VERZEICHNIS DER ABKURZUNGEN
}

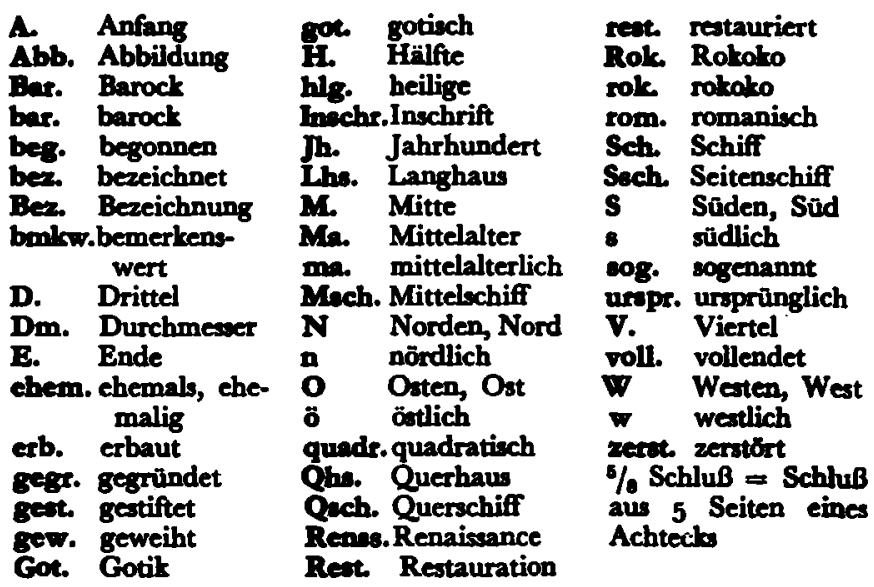

